\title{
CARDIOPULMONARY EFFICIENCY EVALUATION IN WOMEN BETWEEN 50 AND 80 YEARS OF AGE IN KUJAWSKO-POMORSKIE VOIVODESHIP, POLAND
}

\author{
OCENA SPRAWNOŚCI KRĄŻENIOWO-ODDECHOWEJ U KOBIET \\ MIĘDZY 50 A 80 ROKIEM ŻYCIA W WOJEWÓDZTWIE KUJAWSKO-POMORSKIM
}

\author{
${ }^{1}$ Sports Medicine Regional Center in Bydgoszcz, Poland \\ ${ }^{2}$ Department of Physiology, Nicolaus Copernicus University Collegium Medicum in Bydgoszcz, Poland \\ ${ }^{3}$ College of Physical Education and Sport, Nicolaus Copernicus University \\ Collegium Medicum in Bydgoszcz, Poland
}

Su m mary

\begin{abstract}
One of major obstacles in social activity routines is aging and all impairments generated by this inevitable process. Thus, in order to facilitate the effective functioning of elderly people within a society, our attention should be drawn to the quickly advancing consequences of aging. The purpose of this study is to evaluate cardiopulmonary efficiency in a chosen group of women above 50 years of age in KujawskoPomorskie Voivodeship.

3413 women, aged 50-80 years participated in the study. Subjects were divided into six age groups. The BMI was calculated for each participant. All women were subjected to
\end{abstract}

\section{Streszczenie}

Jedną z głównych przeszkód w aktywności społecznej osób starszych wydaje się być wiek i wszystkie związane $\mathrm{z}$ nim nieuniknione procesy. Zatem by ułatwić skuteczne funkcjonowanie osób starszych w społeczeństwie, nasza uwaga powinna być skierowana na szybko postępujące efekty starzenia. Celem tego badania była ocena sprawności krążeniowo - oddechowej u kobiet powyżej 50 roku życia w województwie Kujawsko- Pomorskim. 3413 kobiet w wieku od 50 do 80 lat uczestniczyło w badaniu. Badane kobiety zostały podzielone na sześć grup wiekowych. Wszystkie badane zostały zakwalifikowane i ukończyły 2 minutowy test a 2-minute step test. All participants completed the study. The results of the '2-minute Step' tests showed a decrease of cardiopulmonary efficiency in women. The downslide was correlated with age. Test results indicate unmistakably that cardiopulmonary efficiency diminishes with age. Secondly, bigger cardiopulmonary efficiency will make it easier for women to cope with everyday work. Finally, cardiopulmonary efficiency is shown here to be a parameter worth improving while creating special health programs for seniors.

Key words: circulatory system, fitness test, elderly women, heart rate

Stowa kluczowe: układ krążenia, test sprawnościowy, starsze kobiety, częstość skurczów serca 


\section{INTRODUCTION}

The increasing part of elderly people population within a society is a challenge for the majority of European countries, including Poland. It generates the need to get to know this period of life better as well as to exchange knowledge within numerous disciplines of science on more independent functioning of such people. The increasing number of people at post-productive age has been visible in Polish society for many years. At the same time, the average lifespan is getting longer, currently reaching 79.8 years for women [1]. Hence, it seems that the most vital task of health policy should be not only, as until now, taking care of making life longer, but taking action aiming at positive aging. Aging of a human being is inseparably connected with a notion of health due to a common factor determining the quality of life in a crucial way. In relation to this, healthy aging is evaluated by factors influencing this state i.e. functional independence - determined from the physiological point of view by cardiopulmonary efficiency, muscle strength and flexibility. Physical activity should be the basic natural factor ensuring positive aging. Nevertheless, unfortunately, in the case of majority of elderly people a substantial decrease in physical activity is observed and it is usually limited towards the basic everyday routine, such as shopping, cooking or tidying. Changing lifestyle related to professional inactivity, frequently associated with a diet not suitable for age and activity, leads to obesity, water-electrolyte balance disorders, increased cholesterol level which, together with increased values of blood pressure and pulse, become the risk factors for heart attack or stroke [2]. And still, further maintenance of high physical activity, even on stopping professional life, is one of the basic factors forecasting a longer lifespan in functional independence and autonomy which contributes to subjective as well as objective improvement of elderly people's lives. The physiological and cardiological research show that physical exercises performed systematically increase homodynamic efficiency of a cardiac muscle [3]. It is manifested by a decrease in the frequency of heart contractions while being inactive, an increase in cardiac muscle contraction and an intensification of stroke volume and cardiac output $[4,5]$. Literature indicates that cardiopulmonary efficiency is one of the main factors which influences the ability of elderly people to satisfactorily cope with everyday efforts. Along this line, the purpose of this thesis is to show the current level of elderly people's cardiovascular efficiency with the assistance of a simple but safe test burdensome for this system.

\section{MATERIAL AND METHODS}

The subject population consisted of the Senior Physical Activity Regional Program participants. Testing was conducted in thirty-four towns of Kujawsko-Pomorskie Voivodeship: in Aleksandrów, Barcin, Brodnica, Brzoza, Bydgoszcz, Dąbrowa, Gąsawa, Gniewkowo, Grudziądz, Inowrocław, Kcynia, Koronowo, Lisewo, Lubicz, Łabiszyn, Mrocza, Nakło, Nowa Wieś Wielka, Nowe, Radzyń, Rogowo, Rynarzewo, Rypin, Sławęcinek, Służewo, Szubin, Świecie upon Osa, Tłuchów, Tupadły, Unisław, Włocławek, Zamość and Żnin. The sample of participants was chosen from a population of women aged 50-80. All subjects taking part in the study were obliged to provide informed consent prior to participation as well as undergo qualification tests conducted by a medical practitioner accompanied by a Master of Nursing. The purpose of medical examination was to evaluate the subject's general health condition and also to eliminate those who, due to health problems, were not able to participate in physical exercises not typical for rehabilitation ones. The examination included an interview; blood pressure and heart rate measurement; ECG; lung auscultation; reflex, balance and color vision examining, followed by measurement of height, body mass, waist and hips. On this surface, the factor most specifically taken into consideration was circulatory system and musculoskeletal efficiency. Chronic circulatory, respiratory and skeletal system diseases as well as neurological diseases were the criterion for exclusion from physical fitness examination. Having consulted the specialists, women with pharmalogically settled hypertension and diabetes were allowed to participate in the study. After functional fitness levels were assessed for all subjects, they were required to attend testing sessions conducted by a Master of Physical Therapy in order to measure their physical fitness. Each functional testing was performed in the afternoon, in the same order for every individual subject. Prior to testing, each subject was given instructions and shown how each exercise should be performed by a tester. Testing was conducted in rooms 
which were up to safety standards, with temperature $18-22^{\circ} \mathrm{C}$, with a nurse present in the room. To evaluate cardiopulmonary efficiency of women participating in the study used '2-minute Step' test [6].

The subject population consisted of 3413 women, tested in 2007-2011. The whole group was divided into six age groups: 50-54, 55-59, 60-64, 65-69, 70-74 and 74-79 years. The average age in all age groups was $52.05 \pm 1.59$ in the first age group; $57.1 \pm 1.39$, in the second; $61.72 \pm 1.39$, in the third; $66.65 \pm 1.42$, in the fourth; $71.58 \pm 1.37$, in the fifth and $76.58 \pm 1.44$ in the last one (Table I).

On the basis of weight and height measurements, the BMI was calculated. The mean values of the BMI were: 28 in the first age group; 28.39 in the second ; 28.4 in the third; 29.1 in the fourth; 28.3 in the fifth and 28.1 in the last one, respectively (Table I). According to WHO classification, on the basis of the BMI, women examined in the study in all age groups are within range of the first degree of overweight.

Table I. Characteristics of the subjects

\begin{tabular}{|c|c|c|c|c|c|c|c|c|c|c|}
\hline & \multirow[t]{2}{*}{$\begin{array}{l}\text { Age } \\
\text { Group }\end{array}$} & \multirow{2}{*}{$\begin{array}{c}\text { Number } \\
\text { of } \\
\text { subjects }\end{array}$} & \multicolumn{2}{|c|}{ Age (year) } & \multicolumn{2}{|c|}{$\begin{array}{c}\text { Body } \\
\text { height } \\
(\mathrm{cm})\end{array}$} & \multicolumn{2}{|c|}{$\begin{array}{c}\text { Body } \\
\text { weight }(\mathrm{kg})\end{array}$} & \multicolumn{2}{|c|}{ BMI } \\
\hline & & & Mean & SD & Mean & $\mathrm{SD}$ & Mean & SD & Mean & SD \\
\hline 1 & $50-54$ & 853 & 52.0 & \pm 1.6 & 162.1 & \pm 5.6 & 73.6 & \pm 13.5 & 28.0 & \pm 4.9 \\
\hline 2 & $55-59$ & 1131 & 57.1 & \pm 1.4 & 160.6 & \pm 6.1 & 73.2 & \pm 12.6 & 28.4 & \pm 4.6 \\
\hline 3 & 60-64 & 884 & 61.7 & \pm 1.4 & 160.4 & \pm 5.4 & 73.0 & \pm 12.8 & 28.4 & \pm 4.7 \\
\hline 4 & 65-69 & 350 & 66.6 & \pm 1.4 & 159.4 & \pm 5.9 & 74.0 & \pm 12.7 & 29.1 & \pm 4.9 \\
\hline 5 & $70-74$ & 145 & 71.6 & \pm 1.4 & 159.2 & \pm 5.7 & 72.2 & \pm 11.2 & 28.3 & \pm 3.9 \\
\hline 6 & $75-79$ & 50 & 76.6 & \pm 1.4 & 157.6 & \pm 7.0 & 69.6 & \pm 9.2 & 28.1 & \pm 3.8 \\
\hline
\end{tabular}

\section{RESULTS}

All the participants of the study performed the test - '2-minute Step' - evaluating cardiopulmonary efficiency. The biggest number of repetitions $117 \pm 15.1$ were done by the youngest group of women (50-54 years). In the second age group (55-59 years) the result was $115.4 \pm 14.6$ repetitions. In the next age group - 60-64 years - the result was $113.3 \pm 14.7$. In the fourth age group (65-69 years) the result was similar $113.3 \pm 15.4$ repetitions. In the last two age groups results were also weaker than in the previous ones and were, respectively, for the group 70-74 years $108.9 \pm 16.8$ repetitions and for the group 75-79 years $103.5 \pm 19.9$ repetitions. At the same time, all age groups displayed the decrease of the heart rate value after 30 seconds from the exertion in comparison to 1 second from the exertion. In the first age group there were 17 systoles fewer, in the second one and in the third one there were on average 16 systoles fewer. In the fourth group, respectively, one systole fewer, namely 15 , and in the fifth group one systole fewer 14. The oldest age group displayed on average 18 systoles fewer.

The percentile ranks for the '2-minute Step' test for the subjects can be seen in Table III.

Table II. Study results '2-minute Step' test

\begin{tabular}{|c|c|c|c|c|c|c|c|c|}
\hline & \multirow{2}{*}{$\begin{array}{c}\text { Age } \\
\text { Group }\end{array}$} & $\begin{array}{c}\text { Number } \\
\text { of } \\
\text { subjects }\end{array}$ & \multicolumn{2}{|c|}{$\begin{array}{c}\text { Steps } \\
\text { (number) }\end{array}$} & \multicolumn{2}{|c|}{ HR in 1second } & \multicolumn{2}{|c|}{$\begin{array}{c}\text { HR after 30 } \\
\text { second }\end{array}$} \\
\cline { 4 - 9 } & & Mean & SD & Mean & SD & Mean & SD \\
\hline 1 & $50-54$ & 853 & 117 & \pm 15.1 & 146.8 & \pm 17.2 & 129.6 & \pm 18.1 \\
\hline 2 & $55-59$ & 1131 & 115.4 & \pm 14.6 & 141 & \pm 19.1 & 124.5 & \pm 19.6 \\
\hline 3 & $60-64$ & 884 & 113.3 & \pm 14.7 & 141.1 & \pm 18.3 & 124.8 & \pm 19.3 \\
\hline 4 & $65-69$ & 350 & 113.3 & \pm 15.4 & 135 & \pm 19.6 & 119.5 & \pm 18.9 \\
\hline 5 & $70-74$ & 145 & 108.9 & \pm 16.8 & 130.7 & \pm 20.2 & 116.8 & \pm 20.9 \\
\hline 6 & $75-79$ & 50 & 103.5 & \pm 19.9 & 128.9 & \pm 16.1 & 110.9 & \pm 16.5 \\
\hline
\end{tabular}

Table III. Percentile Ranks for the '2-minute Step' test

\begin{tabular}{|c|c|c|c|c|c|c|}
\hline \multicolumn{7}{|c|}{ 2-minute Step } \\
\hline$\%$ Rank & $50-54$ & $55-59$ & $60-64$ & $65-69$ & $70-74$ & $75-79$ \\
\hline 90 & 135 & 134 & 132 & 135 & 132 & 124 \\
\hline 80 & 129 & 125 & 124 & 123 & 120 & 116 \\
\hline 70 & 123 & 122 & 120 & 120 & 116 & 110 \\
\hline 60 & 119 & 119 & 117 & 118 & 111 & 106 \\
\hline 50 & 116 & 115 & 112 & 114 & 105 & 104 \\
\hline 40 & 113 & 112 & 109 & 110 & 104 & 102 \\
\hline 30 & 109 & 108 & 104 & 106 & 102 & 98 \\
\hline 20 & 106 & 102 & 102 & 101 & 99 & 95 \\
\hline 10 & 101 & 98 & 96 & 93 & 92 & 82 \\
\hline$\overline{\boldsymbol{X}}$ & 117 & 115.4 & 113.3 & 113.3 & 108.9 & 103.5 \\
\hline $\mathrm{SD}$ & 15.1 & 14.6 & 14.7 & 15.4 & 16.8 & 19.9 \\
\hline $\mathrm{n}$ & 853 & 1131 & 884 & 350 & 145 & 50 \\
\hline
\end{tabular}

\section{DISCUSSION}

In Polish society a positive model of old age has not come into existence. Old age, being a natural period in life, is frequently not accepted. Still, it is a value in itself; therefore, it should be accepted mentally and one should be prepared to it physically. It is not easy since Polish seniors are specifically touched by a problem of more diseases. Despite the fact that multiorgan diseases are a typical problem of elderly people, health care is not well prepared for a dynamically changing demographic situation. It is estimated that within 20 years the number of elderly people may reach $30 \%$ of the whole country population.

Cardiopulmonary efficiency embodies the ability of an organism to provide the essential amount of oxygen to start muscle work, while maintaining the efficiency 
of physiological mechanisms which determine the effective adaptation of the system to make exertion.

During the evolution a human organism got adapted to massive physical activity, while changes that have happened in contemporary life limit it. The lack of systemic activation for the elderly in Poland contributes to the movement activity decrease, which leads to the disturbance of the whole system function, especially to the metabolic disorders followed by obesity and other diseases associated with it - heart and vascular diseases. The statistics indicate that circulatory system diseases are the most frequent cause of death for women older than 65 in Poland and are responsible for as much as $58.7 \%$ of all deaths [7]. Naturally, cardiovascular system aging and the number of cardiovascular complications are increasing with age. On the one hand, it is caused by the aging process itself; on the other hand, it is linked to the time of being subjected to risk factors for a longer period. It stems from the increase of the blood vessel stiffness, the increase of the collagen content in cardiac muscle and myocyte overgrowth, the diminishing of arterial vessel flexibility and heart relaxation, especially the left ventricle, and the weakening of the sinus node function [8].

The outcome of 'INTERHEART' research, which included 25 thousand people from 52 countries and different continents, indicates that among the studied risk factors of a possible heart attack, those that autonomously determine it are as follows: excess blood pressure, diabetes, lipid disorders, obesity and smoking; whereas, cardio protective activities include: eating vegetables and fruit, moderate alcohol drinking and regular physical activity [9].

Zdrojewski presents the results which show that 9 million adult Poles have excess blood pressure (31\% of the population) and within a group of people aged over 65 this percentage is as much as $76 \%$ [10]. This outcome is also confirmed by studies conducted within a Polish nationwide research project - Wobasz, carried out in 2003-2005 on a population of 7792 women and 6977 men. According to WHO standard, excess blood pressure was recognized in $32 \%$ of women studied within this project [11]. Such a big population of people with excess pressure is also indicated by a Polish part of HAPIEE project in which a study group consisted of people aged 45-69 years [12].

There are a number of studies both in contemporary literature and a little earlier which show a positive impact of physical activity on people suffering from various problems on the part of the cardiovascular system.

The research conducted by Sacre et al. indicates that moderate exercising has influence on diminishing the risk of cardio-metabolic diseases and it contributes, as one of the factors, to diminishing of artery stiffness [13]. Nyberg et al. indicate that exercising lowers diastolic blood pressure [14]. Research conducted by Evans et al. on 10 persons with the average age of 82.3 years, in which a number of fitness tests were performed, such as 50-foot walking test, indicates that exertion given in appropriately distributed doses makes cardiovascular efficiency, sensitivity to insulin as well as lipid blood profile better and it also diminishes the risk of coronary disease [15].

The study by American scientists from 2012 shows that physical exercises diminish oxidative stress and activate more antioxidative enzymes [16]. Scientists from Japan present the results which show that regular physical activity prevents cardiovascular diseases from happening through lowering proinflammatory factors in a systematic way [17]. In a Norwegian study, in which there were 39 women with the average of age 52 , the task was to exercise on a treadmill 3 times a week for 12 weeks. The outcome of the study showed that the systolic myocardial function and a total peripheral resistance was lowered and it also increased vo2max in both exercising groups [18]. Kostić et al. conducted a study with 60 women aged between 65 and 70 years. Subjects with excess blood pressure and joint pains were not excluded from the study and there were a few women taking anti excess blood pressure medicines. The study demonstrates correlations between the functional fitness test and changes in systolic and diastolic blood pressure influenced by these tests. Functional fitness gives a statistically significant explanation of $35 \%$ of the variance of systolic and diastolic blood pressure on a sample of elderly women [19].

In Poland as well as in Europe there have not been a lot of studies showing the cardiovascular efficiency under the influence of a 2-minute step up test. The majority of conducted studies consist of ambulatory tests performed on treadmills or ergometers by cardiology specialists. They provide an authoritative picture of the systems but, unfortunately, it is difficult to conduct them as population studies due to a longer time necessary for them. This is enabled by a 2 -minute step up test. 
One of the studies is the one done with the assistance of a 2-minute step up test on a group of 694 women from Serbia. They were divided into two age groups. The first one 60-69 years consisted of 354 women, with the average age of $63.75+2.89$ and the other one: 70-80 years of age, consisted of 340 women, with the average age of $73.93+2.94$. The results were as follows: in the first group women made $82.48+26.19$ repetitions and in the second group 81.68+23.27 repetitions [20].

In Poland the biggest number of studies conducted in relation to the problem are performed by Ignasiak. During the study conducted in 2009 on a sample of 60 boarders divided into two groups, one in a sanatorium with the average of age 70.5 years, and the other in a nursing home with the average of age 67.8 years, a 2minute step up test was preformed. The outcome was as follows: for the first group 64.94+17.90 and for the second group 48.26+29.05 [21].

So far, the biggest study in Poland was conducted by Zieliński. In conducted on a sample of 1017 women over 65 years old studies, with a division into 6 age groups he shows his results in relation to American norms. In all age groups Polish citizens achieved significantly weaker results in comparison to American citizens. The differences ranged from 30 repetitions in the youngest age group (60-64) to about 10 repetitions in the oldest age group (90-94 years) [22].

Our study results, in comparison with American norms created by Rikli and Jones, indicate that Polish women achieved a little better results than American women. American norm for the age group 60-64 years is 75-107 repetitions and for the age group 65-69 years it is 73-107 repetitions. Polish women achieved an average of 113 repetitions in both age groups. American norms for a group 70-74 years is 68-101 repetitions, while Polish women achieved 109 repetitions. In the oldest comparable age group (75-79 years) an American norm is 68-100 repetitions, whereas Polish women achieved on average 103 repetitions in comparison to American women [23].

The worldwide literature provides numerous studies, indicating a positive impact of physical exercises as a primary and secondary prevention factor against various diseases; however, a lack of activity is demonstrated as an independent risk factor [24]. Physical activity taken up regularly healthfully influences the heart and vessel functions. Due to physical exertion, the tonus of the vagus nerve increases, the frequency of heart rate slows down diminishing, at the same time, the risk of dangerous ventricular arrhythmias and a sudden death [25]. Other studies also point to the improvement of the coronary arteries as well as peripheral circulation development stimulation due to exertion [26].

\section{ACKNOWLEGDMENTS}

This study was supported by Health Department of the Marshal Office of Kujawsko-Pomorskie Voivodeship.

\section{CONFLICT OF INTEREST}

The authors declare they have no conflict of interest.

\section{REFERENCES}

1. Central Statistical Office of Poland; Prognoza Ludności Polski na lata 2008-2035, Warszawa, 2008b; http://www.stat.gov.pl/gus

2. The Task Force on the Management of Acute Coronary Syndromes of the European Society of Cardiology. Management of acute myocardial infraction in patients presenting with ST-segment elevation. Eur. Heart J. 2003; 24:28-66

3. Pollock M.L, Evans W.J. Resistance training for health and disease: introduction. Med.Sci.Sports Exerc. 1998; 30:10-11

4. Donnelly J.E, Blair S.N, Jakcic J.M, Manore M.M, Ranikin J.W, Smith B.K American College of Sports Medicine. Appropriate physical activity intervention strategies for weight loss and prevention of weight regain for adults. Med.Sci.Sports Exerc. 2009; 41:459- 471

5. Żak M, Grodzicki T. Falls of female patients suffering from cardiovascular diseases - assessment of potential risk factor and individual ability to cope after an anccidental fall. New Medicine 2003; 6:69-72

6. Rikli R., Jones C.J. Senior Fitness Test Manual. Human Kinetics Publishers; 2001

7. WHO Regional Office for Europe; Nierówności w zdrowiu w Polsce. 2012; Page 98

8. Wieczorkowska-Tobis K. Zmiany narządowe w procesie starzenia. Pol.Arch.Med.Wewn. 2008; 118:63-68

9. Yusuf S, Hawken S, Ounpuu S, et al. Effect of potentially modifiable risk factors associated with myocardial infraction in 52 countries (the INTERHEART study): case control study. Lancet 2004; 364: 937-952

10. Zdrojewski T. Prevelance and awareness of arterial hypertension In Poland and in the world. Postępy Nauk Medycznych 2011; 3:4-10

11. Polakowska M, Piotrowski W. Socioeconomic factors and prevelance of arterial hypertension in rural and urban 
areas. Wobasz study. Medycyna Ogólna 2010; 16(XLV), 2: $162-173$

12. Doryńska A, Polak M, Kozela M, Szafraniec K et al. Czynniki ryzyka chorób układu krążenia u dorosłych mieszkańców Krakowa i całej Polski. Wyniki badania Wobasz i polskiej części projektu HAPIEE. Przegląd Epidemiologiczny 2015; 69: 175-180

13. Sacre J.W, Jennings G, Bronwyn A. Kingwell Exercise and diet ary influences on arterial stiffness in cardiometabloic disease. Hypertension 2014; 63: 888-893

14. Nyberg M, Seidelin K, Rostgaard Andersen T, Neumann Overby N, Ylva Hellsten, Bangsbo J. Biomarkers of vascular function in premenopausal and recent postmenopausal women of similar age: effect of exercise training. American Journal of Physiology - Regulatory, Integrative and Comparative Physiology 2014; DOI: 10.1152/ajpregu.00539.2013

15. Evans E, Racette S, Peterson L, Villareal D, Greiwe J, Holloszy J. Aerobic power and insulin action improve in response to endurance exercise training in healthy 77-87 years old. Journal of Applied Physiology 2005; 98:40-45

16. Traustadottir T, Davies S, Su Yali, Choi Leena, BrownBorg H, Jackson Roberts, Harman M. Oxidative stress In older adults: effects of physical fitness. AGE 2012; 34:969-982

17. Miyaki A, Meada S, Choi Y, Akazawa N, Tanabe Y, Ajisaka R. Habitual aerobic exercise increase plasma pentraxin 3 levels In middle-aged and elderly women. Appl.Physiol.Nutr.Metab. 2012; 37:907-911

18. Molmen-Hansen H, Stolen T, Aamont L, Schjerve Ekeberg I, Tyldum A, Bjork Ingul, Asbjorn Stoylen Aerobic interval training reduces blood pressure and improves myocardial function in hypertensive patients. European Journal of Preventive Cardiology 2011; 19:151- 160

19. Kostić R, Mladenović I, Mikalaćki M. The relationship between physical/functional fitness and the blood pressure of elderly men and women. Facta Universitatis 2007; Vol.5, 1: 75-84
20. Kostić R, Pantelić S, Miletić D, Uzunović S, Aleksandrović M. Indicators of physical fitness among the elderly based of the values of their BMI. Facta Universitatis Series: Physical Education and Sport 2012; Vol.10 (1): 1-11

21. Ignasiak Z, Kaczorowska A, Katan A, Domaradzki J. Evaluation of fitness of elderly women by means of Fullerton Test. Fizjoterapia 2009; 17, 2: 48-52

22. Zieliński W. Physical ability of polish and American population aged more then 64 years old Annales UMCS Lublin 2005; Vol. LX, SUPPL. XVI, 664, 432-435

23. Jones J, Rikli R. Measuring functional fitness of older adults. The Journal on Active Ageing 2002; 3:24-30

24. Bauman A. Use of population attributable risk In under standing the helath benefits of physical activity. British Journal of Sports Medicine 1998; 32(4): 279-280

25. Liao D, Cai J, Rosamond W et al. Cardiac automatic function and incident coronary heart disease: a population- based case-cohort study. The ARIC Study. Atheosclerosis Risk in Communities Study. Am. J. Epidemiol. 1997; 145: 696-706

26. Hambrecht R, Wolf A, Gielen S et al. Effect of exercise on coronary endothelial function in patients with coronary artery disease. N.Engl. J. Med. 2000; 342: 454460

Address for correspondence:

Andrzej Chęsy, Msc

Regionalny Ośrodek Medycyny Sportowej

ul.Tadeusza Rejtana 1

85-032 Bydgoszcz

e-mail: andrzej.chesy@gmail.com

Wojciech Sikorski, Katarzyna Dmitruk, Małgorzata

Tafil-Klawe: kizfizjol@cm.umk.pl

Gabriel Chęsy, Andrzej Rakowski, Paweł Rakowski:

rehabilitacja.roms@wp.pl

Tomasz Zegarski: stwfis@cm.umk.pl

Received: 18.02.2016

Accepted for publication: 23.03.2016 